\title{
Efficacy of in-vitro Propagation among Some Advanced Potato Clones and Evaluation of Yield Character for the Production of Nucleus Seed
}

\author{
Naznin Sultana ${ }^{1}$, Md. Mosharraf Hossain Molla ${ }^{2}$, Ekramul Hoque ${ }^{1}$, \\ Shahinoor Rahman ${ }^{3}$, Mashiur Rahman ${ }^{4}$ Ananya Prova ${ }^{5}$ and Abu Sayed ${ }^{6}$
}

${ }^{1}$ Department of Biotechnology, Sher-e-Bangla Agricultural University, Dhaka, Bangladesh

${ }^{2}$ Tuber Crop Research Center, Bangladesh Agricultural Research Institute, Gazipur, Bangladesh

${ }^{3}$ Department of Entomology, EXIM Bank Agricultural University, Bangladesh

${ }^{4}$ Department of Chemical and Biochemical Engineering,

Technical University of Denmark, Denmark

${ }^{5}$ Department of Plant Pathology, EXIM Bank Agricultural University Bangladesh

${ }^{6}$ Department of Agricultural Engineering, EXIM Bank Agricultural University Bangladesh

*Corresponding author

\begin{tabular}{|c|c|}
\hline \multicolumn{2}{|r|}{ A B S T R A C T } \\
\hline & \multirow{7}{*}{$\begin{array}{l}\text { This experiment was done to investigate in vitro propagation and nucleus seed production } \\
\text { efficiency of Bangladesh Agricultural Research Institute (BARI) developed clone potato } \\
\text { varieties. In vitro shoots of potato varieties BARI Alu-35, BARI Alu-36, BARI Alu-37, } \\
\text { BARI Alu- } 40 \text {, BARI Alu- } 46 \text { and BARI Alu- } 62 \text { were used as planting materials and BARI } \\
\text { Alu-7 was used as check variety. There was significant difference among the growth } \\
\text { parameters of in vitro plantlets of the potato varieties. The maximum number of leaf } \\
\text { (14.80), length of shoot }(99.98 \mathrm{~cm}) \text { weight of fresh shoot }(1.66 \mathrm{mg}) \text { was observed in BARI } \\
\text { Alu-36. The highest length of root }(5.54 \mathrm{~cm}) \text {, maximum number of primary root }(17.00) \text {, } \\
\text { number of secondary root }(28.20) \text { and fresh weight of root }(0.359 \mathrm{mg}) \text { were observed in } \\
\text { BARI Alu-36. The variety BARI Alu-36 showed better performance on most of the } \\
\text { morphological traits under in vitro condition. On the other hand, survival percentage and } \\
\text { nucleus seed }\left(\mathrm{G}_{1} \text { generation) production of potato have been done from virus free in vitro }\right. \\
\text { plantlets of potato at net house. Maximum number and weight of } \mathrm{G}_{1} \text { seed tuber per plant is } \\
52.4 \text { and } 358.0 \mathrm{~g} \text { respectively was recorded in the BARI Alu- } 46 \text {. }\end{array}$} \\
\hline & \\
\hline & \\
\hline $\begin{array}{l}\text { se } \\
\mathrm{Ti} \\
\mathrm{Pr}\end{array}$ & \\
\hline Article Info & \\
\hline $\begin{array}{l}\text { Accepted: } \\
\text { 26 June } 2018 \\
\text { Available Online: } \\
\text { 10 July } 2018\end{array}$ & \\
\hline & \\
\hline
\end{tabular}

\section{Introduction}

Potato (Solanum tuberosum L.) is the most important vegetable crop of Bangladesh. It alone contributes to about $63 \%$ of the total annual vegetable production in Bangladesh (Islam, 2012). Total area under potato cultivation is 4,62,032 hectares and total potato production has been estimated $89,50,024$ metric tons. Average yield of potato has been estimated 19.371 metric tons per hectare (BBS, 2014). Now potato stands as a short duration winter crop in sub-tropical countries like Bangladesh (Hossain, 2011). Most of the varieties of potato have been developed through ordinary selection and by 
conventional breeding which is very prolonged procedure. Recently plant genetic engineering techniques have been providing a new opportunity for crop improvement. An efficient tissue culture system is thought to be crucial to the success of plant genetic transformation. Transferring genes into plants it is prerequisite to have efficient callus induction and plantlet regeneration system (Hamrick et al., 2000).

The regeneration of plants from cell and tissue culture represent an essential component of biotechnology and have the potentiality not only to improve the existing cultivars, but also for the generation of novel plants in a comparatively short time compared to conventional breeding (Khadiga et al., 2009).The obtained tubers are small (1-25 g wt.) and high quality commonly known as mini tuber or nucleus seed. In vitro-produced disease-free potato clones combined with conventional multiplication methods have become an integral part of seed production in many countries (Naik and Sarkar, 2000).In vitro regeneration of potato has been reported from different explants on MS medium and different growth regulators for diseases free good quality plantlet or seed and pathogen free planting materials (Hossain, 1994; Rabbani et al., 2001; Zaman et al., 2001). in vitro culture techniques and their practical applications in clonal propagation, germplasm storage, production of healthy virus-free plants and breeding (Vinterhalter et al., 2011). Under Bangladesh condition, very few reports are available regarding the varietal effect and explants on plantlet multiplication under in vitro condition.

So, the present research is to provide the information on high frequency plantlet production to meet the producer demand as well as morphological performances of different varieties under in vivo condition.

\section{Materials and Methods}

The experiment was conducted during the period from April 2016 to February 2017 to investigate in vitro propagation and nucleus seed $\left(\mathrm{G}_{1}\right)$ production efficiency of Bangladesh Agricultural Research Institute (BARI) developed clone potato varieties. The experiments were conducted at the laboratory and net house of Tuber Crop Research Center (TCRC), BARI, Gazipur. In laboratory condition, Completely Randomized Design (CRD) with three replications and in field condition Randomized Complete Block Design (RCBD) having three replications were used.

\section{Plant materials}

The tuber of potato varieties BARI Alu-7, BARI Alu-35, BARI Alu-36, BARI Alu-37, BARI Alu-40, BARI Alu-46 and BARI Alu62 were used as plant materials for the experiment. BARI Alu-7 has been used as check variety. Stem segments having 2-3 nodes from in vitro plantlets were used for micropropagation and determining IBA effect on root production.

\section{Culture media}

Murashige and Skoog medium, Liquid medium were used as culture medium for in vitro regeneration.

\section{Stock solutions preparation}

The first step in the preparation of the medium is the preparation of stock solutions of the various constituents of the MS medium. As different media constituents were required in different concentrations, separate stock solutions for the macronutrients, micronutrients, Fe-EDTA (Iron stock), vitamins and growth regulators were prepared separately for ready use. Other necessary 
solution like $1 \mathrm{~N} \quad \mathrm{NaOH}, \quad 70 \%$ ethanol, preparation of MS media and Agar media and all other necessary works were done by maintaining proper guideline.

Preparation of explants, inoculation and subculture

The shoot of potato was used as explants. Disinfected shoots were then cut into small segments and kept under sterilized distilled water into sterilized petridishes to keep the shoot alive. Explants were directly inoculated to each vial containing $25 \mathrm{ml}$ of MS liquid medium. The vials were plugged crocked and total operation was done in the laminar airflow cabinet in sterile condition. The regenerated plantlets were subcultured into semisolid media after 7 days. The regenerated plantlets were subcultured after 4 week of inoculation. The shoot was cut into small pieces and placed on prepared sterilized MS medium. The subcultured vials were then inoculated at $25 \pm 1^{0} \mathrm{C}$ with $16 \mathrm{~h}$ photo period. Repeated subculture was attended at regular interval of 28 days.

\section{Data collection}

Data on the following parameters were recorded under in vitro condition. Days required for shoot and root appearance: Days to well-developed shoot and root: Length of the shoot or height of the plant $(\mathrm{cm})$ : Length of the root (cm.): Number of leaves per explant: Fresh and Dry weight of the shoot and root (mg) was measured in $\mathrm{mg}$ by a digital balance using following formula:

Fresh and Dry weight of root $/$ shoot $(\mathrm{mg})=$

Total weight of shoot/root

Total number of shoot/root measured

The plantlets (grown in vitro) about $6 \mathrm{~cm}$ height were transferred to the net house and were kept in a shady condition without removing the lids. The beds of the net house were properly ploughed and were covered with a mixture of sand, decomposed cow dung, burnt rice husk and coconut dust $(1: 1: 1: 1 \mathrm{v} / \mathrm{v})$. The mixture was sterilized properly to avoid damping off disease caused by soil borne pathogens of the transplant. After two weeks, the plantlets were transplanted in beds under net house. Beds were drenched with fungicides before planting. Three to four water sprays were given daily with a sprayer to keep the soil moist and maintained humidity for initial one week. Additional soil substrate was added on the nursery beds to bury lower nodes. The crop was allowed to mature and mini tubers were harvested. Data on yield and yield contributing characters were recorded. $\mathrm{G}_{1}$ generation seeds were kept in the cold storage for using as a planting material in the next crop season for breeder seed production.

\section{Statistical analysis}

The data obtained for different characteristics were statistically analyzed to find out the significance difference among the treatments. The mean values of all the recorded characteristics were evaluated and analysis of variance was performed by the ' $F$ ' (variance ratio) test using MSTAT-C software. The significance of the difference among the treatment means was estimated by Duncan's Multiple Range Test (DMRT) at 5\% level of probability.

\section{Results and Discussion}

\section{In vitro propagation of BARI developed clone potato varieties}

\section{Days to shoot initiation}

Significant variation was observed among the different varieties of potato on days to first shoot initiation (Table 1). The maximum days 
to shoot initiation were recorded in BARI Alu7 (6.40 days) and BARI Alu- 35, BARI Alu36 and BARI Alu- 37 required minimum 6.00 days.

\section{Number of leaf per plant}

Number of leaf of potato varieties under study varied significantly among each other (Table 1). The maximum number of leaf (14.80) was recorded from BARI Alu- 36, which was statistically identical. The minimum number of leaf (6.20) was observed from BARI Alu7.

\section{Length of shoot $(\mathrm{cm})$}

Length of shoot of potato plantlet varied significantly among the varieties under study (Table 1). The highest length of shoot (9.98 $\mathrm{cm}$ ) was recorded from BARI Alu- 36, while the lowest length of shoot $(3.76 \mathrm{~cm})$ was observed from BARI Alu- 7 which was statistically similar to all variety except BARI Alu- 36.

\section{Fresh weight of shoot (mg)}

Potato varieties were influenced by the fresh weight of shoot. The maximum weight of fresh shoot (1.669 mg) was observed in BARI Alu- 36 and the minimum weight $(0.096 \mathrm{mg})$ was found in BARI Alu- 7 (Table 1).

\section{Dry weight per plant (mg)}

The dry weight of shoot was not significantly influenced by variety of potato. The maximum dry weight per plant $(0.00922 \mathrm{mg})$ was observed in BARI Alu- 36 and the minimum dry weight $(0.00572 \mathrm{mg})$ was observed in BARI Alu- 7 (Table 1).

From table 1 we can conclude that, BARI Alu36 perform better in contrast of other clones of potato variety.

\section{Days to root initiation}

Significant variation was observed among different variety of potato on days to first root initiation (Table 2).

The maximum days to root initiation were recorded in BARI Alu- 7 (5.8 days) and BARI Alu- 36 required minimum 3.80 days.

\section{Length of root $(\mathrm{cm})$}

Length of root of potato plantlet varied significantly among the varieties under study (Table 2). The highest length of root $(5.54 \mathrm{~cm})$ was recorded from BARI Alu- 36, while the lowest length of shoot $(1.50 \mathrm{~cm})$ was observed from BARI Alu- 7 which was statistically similar with BARI Alu- 35.

\section{Number of primary root}

Number of primary root was significantly influenced by varieties under study (Table 2). The maximum number of primary root (17.00) was recorded from BARI Alu- 36, which was statistically identical. The minimum number of leaf (10.40) was observed from BARI Alu7.

\section{Number of secondary root}

Number of secondary root varied significantly for different variety (Table 2). The highest number of secondary root (28.20) was recorded from BARI Alu- 36, whereas the lowest number of secondary root (0.6) was found from BARI Alu- 7.

\section{Fresh weight of root (mg)}

Potato variety significantly influenced the fresh weight of root. The maximum weight of fresh root $(0.359 \mathrm{mg})$ was observed in BARI Alu- 36 and the minimum weight $(0.089 \mathrm{mg})$ was found in BARI Alu- 7 (Table 2).

Dry weight of root per plant (mg) 
The dry weight of root per plant was significantly influenced by variety of potato. The maximum dry weight of root per plant $(0.00112 \mathrm{mg})$ was observed in BARI Alu- 36 and the minimum dry weight of root $(0.00402 \mathrm{mg})$ was observed in BARI Alu- 7 (Table 2).

From table 2, we make a decision that, considering all of the parameter, BARI Alu36 are the best clone among all other potato varieties of Bangladesh.

Evaluation of nucleus seed production among BARI developed clone potato varieties

\section{Plant height (cm)}

Plant height of seven potato varieties varied significantly under net house conditions (Table 3). The tallest plants $(86.73 \mathrm{~cm})$ were recorded in BARI Alu- 46 followed by BARI Alu-40 (77.43). There was no significant difference between the variety BARI Alu- 7 and BARI Alu- 35. The shortest plant $(\mathrm{cm})$ was observed in BARI Alu- 35.

\section{Number of shoot per plant}

Number of shoot per plant of potato varied significantly for different varieties (Table 3 ). The highest number of shoot per plant (9.00) was recorded from potato variety BARI Alu35. The lowest number of shoot per plant (1.20) was found from BARI Alu- 37. Number of shoot per plant produced by BARI Alu- 7 and BARI Alu- 62 was statistically identical (Table 3).

\section{Number of leaf per plant}

Significant variation was observed among the different varieties of potato on number of leaf per plant (Table 3). The maximum number of leaves per plant (134.50) was recorded from potato variety BARI Alu- 35. The lowest number of leaf per plant (23.13) was found from BARI Alu- 36 which was statistically similar with BARI Alu- 37.

Table.1 Effect on varieties on days to shoot initiation, number of leaf per plant, shoot length, fresh and dry weight of the shoot of potato

\begin{tabular}{|c|c|c|c|c|c|}
\hline Treatment & $\begin{array}{c}\text { Days to shoot } \\
\text { initiation }\end{array}$ & $\begin{array}{c}\text { No. of } \\
\text { leaf/plant }\end{array}$ & $\begin{array}{c}\text { Shoot length } \\
(\mathrm{cm})\end{array}$ & $\begin{array}{c}\text { Fresh weight of } \\
\text { shoot }(\mathrm{mg})\end{array}$ & $\begin{array}{c}\text { Dry weight of } \\
\text { shoot (mg) }\end{array}$ \\
\hline BARI Alu- 7 & $6.80 \mathrm{a}$ & $6.20 \mathrm{~d}$ & $3.76 \mathrm{~b}$ & $0.09552 \mathrm{~b}$ & $0.00572 \mathrm{a}$ \\
\hline BARI Alu- 35 & $6.00 \mathrm{~b}$ & $10.20 \mathrm{bc}$ & $4.70 \mathrm{~b}$ & $0.79900 \mathrm{~b}$ & $0.00624 \mathrm{a}$ \\
\hline BARI Alu- 36 & $6.00 \mathrm{~b}$ & $14.80 \mathrm{a}$ & $9.98 \mathrm{a}$ & $1.66900 \mathrm{a}$ & $0.00922 \mathrm{a}$ \\
\hline BARI Alu- 37 & $6.00 \mathrm{~b}$ & $13.20 \mathrm{ab}$ & $4.56 \mathrm{~b}$ & $0.67110 \mathrm{~b}$ & $0.00822 \mathrm{a}$ \\
\hline BARI Alu- 40 & $6.60 \mathrm{a}$ & $9.80 \mathrm{c}$ & $4.22 \mathrm{~b}$ & $0.12160 \mathrm{~b}$ & $0.00842 \mathrm{a}$ \\
\hline BARI Alu- 46 & $6.40 \mathrm{ab}$ & $12.00 \mathrm{abc}$ & $4.20 \mathrm{~b}$ & $0.68270 \mathrm{~b}$ & $0.00908 \mathrm{a}$ \\
\hline BARI Alu- 62 & $6.40 \mathrm{ab}$ & $12.00 \mathrm{abc}$ & $4.24 \mathrm{~b}$ & $0.20310 \mathrm{~b}$ & $0.00642 \mathrm{a}$ \\
\hline LSD $(0.05)$ & 0.53 & 3.04 & 1.33 & 0.71140 & 0.00413 \\
\hline CV $(\%)$ & 6.47 & 10.85 & 7.84 & 9.86000 & 9.98000 \\
\hline
\end{tabular}


Table.2 Effect of varieties on days to root initiation, root length, no. of primary and secondary root per plant, fresh and dry weight of root per plant of potato

\begin{tabular}{|c|c|c|c|c|c|c|}
\hline Treatment & $\begin{array}{c}\text { Days to } \\
\text { root } \\
\text { initiation }\end{array}$ & $\begin{array}{c}\text { Root } \\
\text { length } \\
(\mathrm{cm})\end{array}$ & $\begin{array}{c}\text { No. of } \\
\text { primary } \\
\text { root/plant }\end{array}$ & $\begin{array}{c}\text { No. of } \\
\text { secondary } \\
\text { root/plant }\end{array}$ & $\begin{array}{c}\text { Fresh weight } \\
\text { of root (mg) }\end{array}$ & $\begin{array}{c}\text { Dry } \\
\text { weight of } \\
\text { root (mg) }\end{array}$ \\
\hline BARI Alu- 7 & $5.80 \mathrm{a}$ & $1.80 \mathrm{c}$ & $10.40 \mathrm{~b}$ & $0.60 \mathrm{c}$ & $0.0895 \mathrm{~b}$ & $0.0040 \mathrm{c}$ \\
\hline BARI Alu- 35 & $4.20 \mathrm{bc}$ & $1.82 \mathrm{c}$ & $12.80 \mathrm{ab}$ & $7.80 \mathrm{~b}$ & $0.1941 \mathrm{ab}$ & $0.0073 \mathrm{abc}$ \\
\hline BARI Alu- 36 & $3.80 \mathrm{c}$ & $5.54 \mathrm{a}$ & $17.00 \mathrm{a}$ & $28.20 \mathrm{a}$ & $0.3591 \mathrm{a}$ & $0.0112 \mathrm{a}$ \\
\hline BARI Alu- 37 & $4.00 \mathrm{c}$ & $3.02 \mathrm{~b}$ & $13.80 \mathrm{ab}$ & $3.60 \mathrm{c}$ & $0.2874 \mathrm{ab}$ & $0.0090 \mathrm{ab}$ \\
\hline BARI Alu- 40 & $5.00 \mathrm{ab}$ & $2.36 \mathrm{bc}$ & $14.00 \mathrm{ab}$ & $6.60 \mathrm{~b}$ & $0.1282 \mathrm{ab}$ & $0.0046 \mathrm{bc}$ \\
\hline BARI Alu- 46 & $5.80 \mathrm{a}$ & $2.12 \mathrm{bc}$ & $12.80 \mathrm{ab}$ & $2.60 \mathrm{c}$ & $0.1064 \mathrm{ab}$ & $0.0063 \mathrm{bc}$ \\
\hline BARI Alu- 62 & $4.00 \mathrm{c}$ & $2.94 \mathrm{~b}$ & $15.00 \mathrm{ab}$ & $0.80 \mathrm{c}$ & $0.2864 \mathrm{ab}$ & $0.0033 \mathrm{c}$ \\
\hline LSD $(0.05)$ & $\mathbf{0 . 8 6 1 9}$ & $\mathbf{1 . 0 1 8}$ & $\mathbf{5 . 2 7 6}$ & $\mathbf{2 . 8 6 2}$ & $\mathbf{0 . 2 2 6 1}$ & $\mathbf{0 . 0 0 4 1}$ \\
\hline CV $(\%)$ & $\mathbf{6 . 4 7}$ & $\mathbf{4 . 7 9}$ & $\mathbf{9 . 5 3}$ & $\mathbf{1 0 . 6 1}$ & $\mathbf{8 . 7 5 0 0}$ & $\mathbf{1 0 . 0 9 0 0}$ \\
\hline
\end{tabular}

Table.3 Effect of varieties on plant height, number of shoot, leaf, tuber and weight of tuber per plant

\begin{tabular}{|l|c|c|c|c|c|}
\hline \multicolumn{1}{|c|}{ Treatment } & $\begin{array}{c}\text { Plant height } \\
(\mathrm{cm})\end{array}$ & $\begin{array}{c}\text { No. of } \\
\text { shoot/plant }\end{array}$ & $\begin{array}{c}\text { No. of } \\
\text { leaf/plant }\end{array}$ & $\begin{array}{c}\text { No. of } \\
\text { tuber/plant }\end{array}$ & $\begin{array}{c}\text { Weight of } \\
\text { tuber/plant }\end{array}$ \\
\hline BARI Alu- 7 & $65.33 \mathrm{~d}$ & $4.20 \mathrm{~d}$ & $74.73 \mathrm{~d}$ & $21.20 \mathrm{~d}$ & $307.30 \mathrm{~b}$ \\
\hline BARI Alu- 35 & $65.53 \mathrm{~d}$ & $9.00 \mathrm{a}$ & $134.50 \mathrm{a}$ & $37.40 \mathrm{~b}$ & $142.30 \mathrm{f}$ \\
\hline BARI Alu- 36 & $51.53 \mathrm{f}$ & $2.40 \mathrm{e}$ & $23.13 \mathrm{f}$ & $16.00 \mathrm{~g}$ & $195.50 \mathrm{~d}$ \\
\hline BARI Alu- 37 & $57.73 \mathrm{e}$ & $1.20 \mathrm{f}$ & $23.33 \mathrm{f}$ & $18.60 \mathrm{f}$ & $114.70 \mathrm{~g}$ \\
\hline BARI Alu- 40 & $77.53 \mathrm{~b}$ & $5.00 \mathrm{c}$ & $88.13 \mathrm{~b}$ & $30.40 \mathrm{c}$ & $182.70 \mathrm{e}$ \\
\hline BARI Alu- 46 & $86.73 \mathrm{a}$ & $5.40 \mathrm{~b}$ & $85.53 \mathrm{c}$ & $52.40 \mathrm{a}$ & $358.30 \mathrm{a}$ \\
\hline BARI Alu- 62 & $68.40 \mathrm{c}$ & $4.00 \mathrm{~d}$ & $59.13 \mathrm{e}$ & $19.40 \mathrm{e}$ & $256.90 \mathrm{c}$ \\
\hline LSD $(0.05)$ & $\mathbf{1 . 9 8}$ & $\mathbf{0 . 2 3}$ & $\mathbf{1 . 9 7}$ & $\mathbf{0 . 2 2}$ & $\mathbf{2 . 8 3}$ \\
\hline CV(\%) & $\mathbf{7 . 6 5}$ & $\mathbf{8 . 8 1}$ & $\mathbf{7 . 5 9}$ & $\mathbf{6 . 4 5}$ & $\mathbf{5 . 7 1}$ \\
\hline
\end{tabular}

\section{Number of tubers per plant}

Number of tuber per plant varied significantly in different varieties under study (Table 3). The highest number of tuber (52.40) was recorded from BARI Alu- 46 followed by 37.40 in BARI Alu-40.The lowest number of tuber (18.60) was found from BARI Alu- 37. Weight of tuber

Average weight of tuber varied significantly for different in varieties at net house condition (Table 3). The maximum weight of tuber (358.30g) was recorded from BARI Alu- 46. 
The minimum average weight of tuber $(142.30 \mathrm{~g})$ was found from BARI Alu- 35. From the table 3, it's clear that BARI Alu- 46 perform best among other contrasting potato clones, so this variety may the suitable for the production of nucleus seed.

Based on the results and discussion it can be concluded that the variety BARI Alu-36 showed better performance (Number of leaf, length of shot, weight of fresh root, length of root, maximum number of primary root, number of secondary root and fresh weight of root) under in vitro condition.Growth, development and yield of $\mathrm{G}_{1}$ seeds/minituber per plant was found better in BARI Alu- 46.

\section{References}

BBS (Bangladesh Bureau of Statistics), 2014. Yearbook of Agricultural Statistics in Bangladesh, Bangladesh Bureau of Statistics, Ministry of Planning, Government of the People's Republic of Bangladesh.

Hamrick, J.L. and Godt., M.J. 2000. Allozyme diversity in plant species. In: Plant Population Genetics, Breeding and Genetic Resources eds. Brown AHD, Clegg MT, Kahler AL, Weir BS., pp. 43-63.

Hossain, M.J. 1994. In vitro propagation of potato Solanum tuberosum L. J. Plant Tissue Cult., 4(1):33-37.

Hossain, M.S. 2011. Yield potential, storage behavior and degeneration of potato varieties in Bangladesh. Ph.D. thesis, Bangabandhu Sheikh Mujibur Rahman
Agricultural University, Gazipur-1706, Bangladesh.

Islam, M.R. 2012. Performance studies of twenty-four potato accessions under Mymensingh condition. M.Sc. Thesis, Bangladesh Agricultural University Mymensingh, Bangladesh.

Khadiga, G., Elaleem, A., Modawi, R.S. and Khalafalla, M.M. 2009. Effect of Cultivar and Growth Regulator on In vitro Micropropagation of Potato Solanum tuberosum L. American-Eurasian $J$. Sustainable Agric., 3(3): 487-492.

Naik P Sand Sarkar D. 2000. In vitro propagation and conservation of genetic resources in potato. In: Biotechnology in Horticultural and Plantation Crops (Chadha K L, Ravindran P N and Sahijram Leela, eds.), pp. 369-406. Malhotra Publishing House, New Delhi.

Rabbani, A., Askari, B., Abbasi, N.A., Bhatti, M. and Quraishi, A. 2001. Effect of shoot regeneration in Triticum aestivum and Nicotiana plumbaginifolia tissue cultures using the ethylene inhibitor silver nitrate. Plant Cell Reports.6(1): 1-4.

Vinterhalter, D., Dragićević, I. and Vinterhalter, B. 2011. Potato in vitro Culture Techniques and Biotechnology. Fruit, Vegetable and Cereal Sci. and Biotech., 1(2): 16-45 (Special Issue).

Zaman, M.S., Quershi, A., Hasan, G., Din, R.U., Ali, S., Khabir, A. and Gul, N. 2001. Meristem culture of potato Solanum tuberosum L. for production of virus free plantlets, Online J. Bio. Sci., 1: 898-899.

\section{How to cite this article:}

Naznin Sultana, Md. Mosharraf Hossain Molla, Ekramul Hoque, Shahinoor Rahman, Mashiur Rahman, Ananya Prova and Abu Sayed. 2018. Efficacy of in-vitro Propagation among Some Advanced Potato Clones and Evaluation of Yield Character for the Production of Nucleus Seed. Int.J.Curr.Microbiol.App.Sci. 7(07): 3481-3487. doi: https://doi.org/10.20546/ijcmas.2018.707.404 